\title{
Investigações e Práticas em Escolas Promotoras de Saúde: aproximações com a Teoria Social Cognitiva
}

\section{Roberto Tadeu Iaochite}

\section{Introdução}

Historicamente, a discussão sobre a promoção da saúde na escola remonta ao final do século XVIII na Alemanha, e posteriormente em diversos países europeus e também nos Estados Unidos (FIGUEIREDO; MACHADO; ABREU, 2010). Marcadamente pelo caráter médico-higienista, essas ações chegam ao Brasil no início do século XX com a difícil missão de estancar uma grave crise de saúde pública provocada pelos altos índices de mortalidade, em especial de crianças, decorrentes de doenças atualmente imunopreviníveis, como sarampo, tétano, coqueluche e difteria (LIMA, 1985 apud FIGUEIREDO; MACHADO, ABREU, 2010).

É a partir de 1986, com a divulgação da Carta de Otawa elaborada em uma das conferências da Organização Mundial da Saúde, que o conceito de promoção de saúde é ampliado: perde a característica higienista-assistencialista, sendo concebida sob uma perspectiva e um contexto mais amplo, integral, coletivo, ambiental e interdisciplinar (ROCHA; MARCELO; PEREIRA, 2002). Nessa visão, a saúde passa a ser compreendida como uma condição que pode favorecer a tomada de decisões por parte do indivíduo, assumindo que essa condição é tanto de sua responsabilidade quanto uma responsabilidade política e social das comunidades que o cercam.

É, pois, decorrente dessa concepção que a escola, como um espaço social privilegiado, passa a ser o lócus onde essa prática, isto é, a promoção da saúde possa vir a ser social, política e educacionalmente 
Autoeficácia em Contextos de Saúde, Educação e Política

Roberto Tadeu laochite \& Roberta Gurgel Azzi

Organizadores

para continuar lendo, clique aqui 